\title{
EFEKTIVITAS SERBUK SIMPLISIA BIJI PEPAYA SEBAGAI ANTIBAKTERI PADA UDANG PUTIH (Penaeus merguensis) SELAMA PENYIMPANAN DINGIN
}

\author{
Ahmad Niam Salim, Sumardianto, Ulfah Amalia* \\ Departemen Teknologi Hasil Perikanan, Fakultas Perikanan dan Ilmu Kelautan, \\ Universitas Diponegoro, Jalan Prof. Soedarto, SH. Kampus UNDIP Tembalang Semarang. \\ Telpon 024 7474698, Kode Pos 50275 \\ ${ }^{\star}$ Korespodensi : Ulfah_amalia@yahoo.com \\ Diterima: 5 Desember 2017/ Disetujui: 29 Maret 2018
}

Cara sitasi: Salim AN, Sumardianto, Amalia U. 2018. Efektivitas serbuk simplisia biji pepaya sebagai antibakteri pada udang putih (Penaeus merguensis) selama penyimpanan dingin. Jurnal Pengolahan Hasil Perikanan Indonesia. 21(2): 188-198.

\begin{abstract}
Abstrak
Udang putih (Peneaus merguensis) merupakan salah satu produk perikanan yang memiliki sifat mudah busuk (highly perishable) yang diakibatkan adanya aktivitas bakteri. Serbuk simplisia biji pepaya (C. papaya L.) diketahui mengandung senyawa aktif flavonoid, fenol, tanin dan saponin yang dapat digunakan sebagai senyawa antibakteri. Penelitian ini bertujuan untuk menentukan efektivitas serbuk simplisia biji pepaya untuk memperpanjang masa simpan udang putih selama penyimpanan dingin. Penelitian ini menggunakan Rancangan Acak Lengkap Faktorial (RALF) dengan 2 faktor yaitu konsentrasi serbuk simplisia biji pepaya ( $0 \%$ dan $4 \%$ ) dan lama penyimpanan (0; 4; 8 dan 12 hari). Data terdiri dari analisis fitokimia dan rendemen serbuk simplisia biji pepaya, Total Plate Count (TPC), Total Volatile Base Nitrogen (TVBN), organoleptik dan $\mathrm{pH}$ udang putih hasil penelitian. Rendemen serbuk simplisia biji pepaya yaitu $40,67 \%$ dengan kandungan flavonoid $0,12 \%$, saponin $0,24 \%$, fenol $0,67 \%$, dan tanin $0,72 \%$. Udang putih segar yang disimpan dengan serbuk simplisia biji pepaya konsentrasi $4 \%$ mampu bertahan hingga hari ke-12 dibandingkan dengan udang putih segar tanpa serbuk simplisia (kontrol) yang hanya bertahan hingga hari ke-8. Perbedaan konsentrasi serbuk simplisia biji pepaya dan lama penyimpanan memberikan pengaruh nyata $(\mathrm{p}<5 \%)$ terhadap nilai TPC, $\mathrm{pH}$ serta organoleptik.
\end{abstract}

Kata kunci: antibakteri, biji papaya, penyimpanan dingin, serbuk simplisia, udang putih

\section{The Effectivity of Papaya Seed Simplicia Powder as Antibacterial on White Shrimp during Cold Storage}

\begin{abstract}
White shrimp (Peneaus merguensis) is a highly perishable fishery product due to bacterial activity within its body. The papaya (Carica papaya L.) seed powder has been observed containing bioactive compounds such as flavonoid, phenol, tannin and saponin that proved to haveantibacterial activities. This research was aimed to determine the effectiveness of papaya seed powder on extending the shelf life of white shrimp during storage at chilling temperature. The correlation of the papaya seed powder concentrations $(0 \%$ and 4\%) with storage times (day 0, day 4, day 8 and day 12) was determined using Completely Randomized Design (CRD) method. The Phytochemical analysis and yield of papaya seed powder, Total Plate Count (TPC), Total Volatil Base Nitrogen (TVBN), organoleptic, yield and $\mathrm{pH}$ of white shrimp were observed. The result showed that the yield of papaya seed simplicia powder was $40.67 \%$ with $0.12 \%$ of flavonoids, $0.24 \%$ of saponin, $0.67 \%$ of phenol and $0.72 \%$ of tannin. The quality of the chilled white shrimp stored with $4 \%$ of papaya seed simplicia powder could be maintained up to day 12 compared with the chilled white shrimp without simplicia powder (control) that only lasted until day 8 . The different concentration of papaya seed simplicia powder and storage time gave significant effects $(\mathrm{p}<5 \%)$ to TPC, TVBN, $\mathrm{pH}$ and organoleptic value of white shrimp.
\end{abstract}

Keywords: antibacterial, cold storage, papaya seed, simplicia powder, white shrimp 


\section{PENDAHULUAN}

Udang putih (P. merguensis) merupakan salah satu produk perikanan yang memilliki sifat mudah busuk (highly perishable), maka penanganan yang baik mutlak diperlukan agar mutu udang tetap segar pada saat dikonsumsi. Daya tahan udang putih yang sangat singkat ini dipengaruhi oleh kadar air pada udang yang tinggi mencapai $76,14 \%$. Menurut Novrihansa et al. (2014), kandungan protein udang putih segar yaitu $17,72 \%$, lemak 2,46\%, air 76,14\% dan kadar kolesterol pada udang putih segar $134,05 \mathrm{mg} / 100$ gram. Penanganan pada udang putih segar yang kurang baik akan menyebabkan udang putih segar cepat mengalami kemunduran mutu akibat aktivitas mikroba. Bakteri merupakan salah satu mikroba yang berperan dalam proses pembusukan. Menurut Liviawaty dan Eddy (2010), jenis mikroba utama yang dapat menyebabkan terjadinya proses pembusukan pada ikan segar adalah bakteri. Bakteri dapat berasal dari tubuh ikan yang terkontaminasi dari media tempat hidupnya, lingkungan pengolahan atau penyimpanan. Penelitian terkait pemanfaatan senyawa yang terkandung dalam tanaman sebagai antibakteri telah dilakukan, diantaranya Husni et al. (2015) menggunakan ekstrak etanolik Padina sp. untuk meningkatkan masa simpan ikan kembung hasil penelitian menunjukan bahwa ikan kembung dapat bertahan mutunya selama 6 jam pada penyimpanan suhu kamar.

Senyawa antibakteri merupakan senyawa yang dapat mencegah terjadinya pertumbuhan bakteri serta sebagai pengendali dalam pertumbuhan bakteri, terutama bakteri yang bersifat merugikan (Alfiyaturohmah et al. 2014). Antibakteri banyak ditemukan di alam, antara lain terdapat pada biji pepaya. Menurut Martiasih et al. (2014), biji pepaya diketahui mengandung senyawa kimia seperti golongan fenol, alkaloid dan saponin. Biji pepaya yang berwana putih mengandung senyawa triterpenoid aldehida dengan karakteristik gugus fungsi: $-\mathrm{CH} 2,-\mathrm{CH} 3$, dan $\mathrm{C}=\mathrm{O}$ yang mempunyai potensi sebagai antibakteri. Menurut penelitian Mulyono (2013), biji pepaya memiliki senyawa alkaloid karpain. Karpain merupakan alkaloid yang memiliki cincin laktonat dengan 7 kelompok rantai metilen yang mampu untuk menghambat kinerja beberapa mikroorganisme. Karpain dapat mencerna protein dari mikroorganisme dan mengubahnya menjadi pepton. Biji pepaya juga mengandung senyawa flavonoid. Senyawa ini juga memiliki daya antibakteri dengan mendenaturasi protein sel bakteri dan merusak membran selnya.

Beberapa penelitian terkait pemanfaatan senyawa bioaktif sebagai antibakteri telah dilakukan, diantaranya perendaman ikan bandeng menggunakan larutan lengkuas konsentrasi 5\% selama 2 jam memiliki daya hambat bakteri lebih besar dibandingkan dengan perendaman sebesar 5\% dan 10\% (Suryawati et al. 2011). Perendaman ekstrak jahe sebesar 9\% dan tanaman cocor bebek sebesar 20\% selama 2 jam mampu mempertahankan mutu ikan kembung selama 12 hari masa simpan pada suhu dingin (Susanto et al. 2011). Serbuk simplisia merupakan suatu bahan alami yang mengalami proses pengeringan, selain proses pengeringan serbuk simplisia dibuat dalam bentuk sehalus mungkin untuk memecah sel-sel tumbuhan untuk menjadi lebih kecil dan memperluas permukaannya agar lebih mudah larut dalam pelarut. Menurut Sembiring (2010), pengecilan ukuran bahan bertujuan untukmemperbesar luas permukaan pori-pori simplisia, sehingga kontak antara partikel simplisia dengan pelarut semakin besar. Tujuan dari penelitian ini adalah untuk menentukan efektivitas serbuk simplisia biji pepaya terhadap masa simpan udang putih selama penyimpanan dingin.

\section{BAHAN DAN METODE Bahan dan Alat}

Bahan yang digunakan dalam penelitian ini yaitu udang putih ( $P$. merguensis) yang diambil dari pengepul udang di daerah Mangkang, Semarang, biji pepaya (C. papaya L.) yang diambil di penjual rujak di Tembalang, Semarang, Jawa Tengah. Bahan kimia yang digunakan yaitu PCA (Plate Count Agar), Asam Perklorat, $\mathrm{KH}_{2} \mathrm{PO}_{4}, \mathrm{NaOH}$, $\mathrm{H}_{3} \mathrm{BO}_{3}, \mathrm{HCl}$, Silcon anti-foaming, Indikator $\mathrm{PP}$ dan Indikator Tashiro. Alat yang digunakan pada penelitian ini meliputi timbangan 
analitik (Adventurer ${ }^{\mathrm{TM}}$ China), Oven (Memmert UN 110.en Germany), $\mathrm{pH}$ meter (AMT-507 China), hot plate stirrer (Daihan LabTech Korea), Inkubator (MemmertIN-75 Germany), scoresheet pengujian sensori udang segar, dan scoresheet pengujian hedonik udang segar hasil penelitian.

\section{Metode Penelitian \\ Pembuatan Serbuk Simplisia Biji Pepaya}

Prosedur pembuatan serbuk simplisia biji pepaya mengacu pada prosedur pembuatan serbuk simplisia yang digunakan oleh Masduqi et al. (2014) sampel biji pepaya dikeringkan dengan metode kering angin selama 5 hari, sampel biji pepaya yang sudah semi kering kemudian dihaluskan dengan mesin grinder untuk memperoleh sampel biji pepaya dalam bentuk serbuk yang paling halus agar lebih mudah larut dalam air, setelah itu, serbuk diayak dengan siever untuk mendapatkan ukuran $60 \mu \mathrm{m}$ serbuk simplisia biji pepaya.

\section{Penelitian Tahap I}

Perlakuan pada penelitian tahap I ini adalah perendaman udang putih selama 2 jam menggunakan larutan serbuk simplisia biji pepaya pada konsentrasi yang berbeda antara lain 2\%, 4\%, dan 6\%. Konsentrasi serbuk simplisia biji pepaya terbaik berdasarkan pengujian hedonik udang putih dan kandungan TPC udang putih pada hari ke-4 penyimpanan pada suhu dingin, hal ini berdasarkan pada penelitian Triwibowo et al. (2013), pengaplikasian antibakteri pada sampel udang, jumlah bakteri diamati 4 hari untuk produk yang disimpan pada suhu dingin $\left( \pm 4^{\circ} \mathrm{C}\right)$.

\section{Penelitian Tahap II}

Pada Penelitian tahap II dilakukan hal yang sama dengan penelitian tahap I dengan perbedaan udang disimpan selama 12 hari dengan perendaman konsentrasi serbuk simplisia terbaik hasil penelitian tahap I.

\section{Metode Analisis}

Analisis kimia meliputi analisis kuantitatif flavonoid mengacu pada (Ahmad et al. 2014), analisis kuantitatif fenol mengacu pada (Samin et al. 2014), uji kuantitatif saponin (Mien et al, 2015) dan analisis kuantitatif tanin (Ryanata et al. 2014). Ketiga analisis tersebut dilakukan terhadap ekstrak serbuk simplisia biji pepaya, sedangkan udang segar hasil penelitian meliputi analisis TVBN (BSN 2009) dan pH (BSN 2004).

\section{Analisis TPC (Total Plate Count)}

Analisis mikrobiologi TPC dari udang segar hasil penelitian mengacu pada metode BSN (2006). Analisis TPC dilakukan untuk mengetahui sejauh mana pengurangan jumlah bakteri pada udang segar setelah diberi perlakuan serbuk simplisia biji pepaya.

\section{Analisis Hedonik}

Udang segar hasil penelitian dianalisis berdasarkan tingkat kesukaan panelis, dimana analsis hedonik mengacu pada BSN (2006).

\section{Analisis Data}

Data dianalisa menggunakan uji normalitas, uji homogenitas, ANOVA (Analysis of varians) dan Uji Tukey (beda nyata jujur). Pengolahan data untuk pengujian sensori menggunakan statistika non parametrik dengan metode Kruskal-Wallis, apabila menunjukan hasil yang berbeda nyata, maka dilanjutkan dengan uji Mann-Whitney.

\section{HASIL DAN PEMBAHASAN Metabolit Sekunder (Fenol, Tanin, Flavonoid, Saponin)}

Metabolit sekunder yang dihasilkan biji pepaya seperti senyawa tannin, fenol dan flavonoid mampu dijadikan sebagai antibakteri. Jumlah senyawa metabolit sekunder dari serbuk biji pepaya secara kuantitatif disajikan pada Tabel 1.

Berdasarkan hasil uji kuantitatif serbuk biji pepaya senyawa tanin cenderung memiliki nilai yang lebih tinggi dibandingkan dengan senyawa fenol, saponin dan flavonoid, tanin umumnya memiliki rasa sepat dan lebih bersifat asam, hal tersebut menyebabkan biji pepaya memiliki rasa pahit. Tanin memiliki kemampuan dalam menghambat pertumbuhan bakteri. Menurut Peter et al. (2014) ekstrak biji pepaya 
Tabel 1 Hasil pengujian tanin, fenol, saponin, dan flavonoid secara kuantitatif Table 1 Quantitative analysis of tanin, phenol, saponin and flavonoid

\begin{tabular}{cc}
\hline $\begin{array}{c}\text { Metabolit sekunder/ Secondary metab- } \\
\text { olites }\end{array}$ & Kandungan/ Contents (\%) \\
\hline Tannin & $0.7213 \pm 0.01$ \\
Phenol & $0.6799 \pm 0.009$ \\
Saponin & $0.2468 \pm 0.0007$ \\
Flavonoid & $0.124 \pm 0.01$ \\
\hline
\end{tabular}

konsentrasi $2,5 \%, 5 \%, 7,5 \%$, dan $10 \%$ memiliki potensi untuk menghambat pertumbuhan bakteri Staphylococcus aureus, Pseudomonas aeruginosa, E. coli dan Salmonella typhi. Flavonoid merupakan senyawa polifenol yang tersebar luas di alam, berdasarkan struktur kimia senyawa flavonoid terdiri dari flavonol, flavon, flavanone, katekin, antosianidin dan kalkon (Taufiq et al. 2015). Flavonoid memiliki sifat antioksidan dan juga berpotensi dalam menghambat pertumbuhan bakteri. Flavonoid mengandung senyawa fenol yang bersifat asam dan disebut juga asam karbolat (Rizqiyana et al. 2017). Struktur dinding sel dan sitoplasma bakteri mengandung protein dan lemak, dengan adanya senyawa antibakteri seperti flavonoid sehingga mampu mendenaturasikan protein dan merusak membran sel. Kandungan senyawa flavonoid pada serbuk biji pepaya rendah, hal tersebut dapat disebabkan karena suhu tinggi yang digunakan selama penanganan hingga pengujian diduga mengurangi atau merusak flavonoid yang ada pada biji pepaya. Menurut Masduqi et al. (2014), senyawa bioaktif khususnya fenol membutuhkan pengeringan tanpa menggunakan energi panas karena senyawa fenol memiliki sifat yang sangat sensitif terhadap perlakuan panas.

\section{Penelitian Tahap I}

Penelitian tahap I dilakukan untuk menentukan kemampuan serbuk simplisia biji pepaya dalam menekan pertumbuhan bakteri dan juga untuk mempelajari tingkat kesukaan panelis terhadap udang segar setelah diberi penambahan serbuk simplisia biji pepaya hasil pengujian TPC disajikan pada Tabel 2.

Tabel 2 menunjukkan bahwa penambahan $4 \%$ serbuk simplisia biji pepaya memiliki tingkat kesukaan panelis yang cenderung lebih tinggi dibandingkan konsentrasi yang lain sedangkan untuk kandungan TPC memiliki perbedaan yang tidak signifikan sehingga pada tahap ini diputuskan bahwa konsentrasi serbuk simplisia biji pepaya yang akan diterapkan pada tahap selanjutnya adalah sebesar $4 \%$.

\section{Penelitian Tahap II}

Penelitian tahap II bertujuan untuk menentukan pengaruh penambahan serbuk simplisia dan tanpa penambahan serbuk simplisia biji pepaya terhadap udang putih selama penyimpanan dingin $\left( \pm 4^{\circ} \mathrm{C}\right)(0 ; 4 ; 8$; 12 hari) terhadap parameter hedonik, TPC, TVBN dan $\mathrm{pH}$.

Tabel 2 Nilai TPC dan tingkat kesukaan panelis terhadap udang segar hasil penelitian tahap I (Table 2 TPC value and level of panellists preferences on phase I fresh shrimp results)

\begin{tabular}{|c|c|c|}
\hline \multirow{2}{*}{$\begin{array}{l}\text { Konsentrasi/ } \\
\text { Concentration }\end{array}$} & \multicolumn{2}{|c|}{ Hasil /Results } \\
\hline & TPC $\log (\mathrm{Cfu} / \mathrm{g})$ & Panelist preferences level \\
\hline $2 \%$ & $4.67 \pm 0.04$ & $7.63 \pm 0.33$ \\
\hline $4 \%$ & $4.42 \pm 0.08$ & $8.04 \pm 0.28$ \\
\hline $6 \%$ & $4.40 \pm 0.09$ & $7.81 \pm 0.24$ \\
\hline
\end{tabular}




\section{Kandungan Total Plate Count (TPC) Udang Putih}

Hasil uji TPC yang dilakukan untuk mengetahui jumlah pertumbuhan mikroba pada udang putih dengan penambahan serbuk dan tanpa penambahan serbuk simplisia biji pepaya penyimpanan suhu dingin selama 12 hari disajikan dalam Gambar 1.

Nilai TPC kontrol udang segar pada hari ke-12 dengan nilai TPC paling tinggi dibandingkan dengan perlakuan perendaman serbuk simplisia biji pepaya, hal tersebut menunjukkan bahwa penggunaan serbuk biji pepaya sebagai antibakteri pada udang putih cukup efektif untuk menghambat pertumbuhan bakteri selama penyimpanan dingin. Efektivitas serbuk biji pepaya dapat menghambat pertumbuhan bakteri karena mengandung senyawa bioaktif yang memiliki kemampuan untuk menghambat pertumbuhan bakteri, seperti senyawa tannin yang mampu mengganggu membran sel bakteri. Menurut Marlin et al. (2015) tanin mempunyai sifat dapat mengerutkan membran sel sehingga mengganggu permeabilitas sel. Menurut Nuria et al. (2009) mekanisme kerja tanin sebagai antibakteri adalah menghambat enzim reverse transkriptase sehingga sel bakteri tidak dapat terbentuk.

Nilai TPC semakin mengalami peningkatan selama waktu penyimpanan, karena pertumbuhan bakteri mulai meningkat sejak udang mati. Suhu pusat udang menjadi naik, mengakibatkan bakteri menyerang segera setelah terjadi kerusakan jaringan pada tubuh udang, menyebabkan terjadinya perubahan komposisi pada daging sehingga mengakibatkan pembusukan. Menurut Suparno (2012), pembusukan pada udang disebabkan terdapatnya pembuluh darah dan kotoran di bagian kepala udang. Udang sangat cepat mengalami autolisis protein dan lemak, serta timbul bercak hitam (black spot) pada penanganan yang dilakukan dalam suhu tinggi.

\section{Total Volatile Base Nitrogen (TVBN) Udang Putih}

Analisis TVBN dilakukan untuk mengetahui senyawa-senyawa volatil akibat degradasi protein pada udang putih dengan penambahan serbuk dan tanpa penambahan serbuk biji pepaya pada penyimpanan suhu dingin selama 12 hari disajikan dalam Gambar 2.

Hasil penelitian menunjukan bahwa perlakuan kontrol sudah melewati ambang batasnilai TVBNuntukpenerimaan konsumen pada penyimpanan hari ke-8, dengan nilai TVBN 34,26 mgN/100g, sedangkan pada perlakuan perendaman serbuk biji pepaya melewati ambang batas nilai TVBN untuk penerimaan konsumen pada penyimpanan hari ke-12 dengan nilai 33,6 mgN/100g.

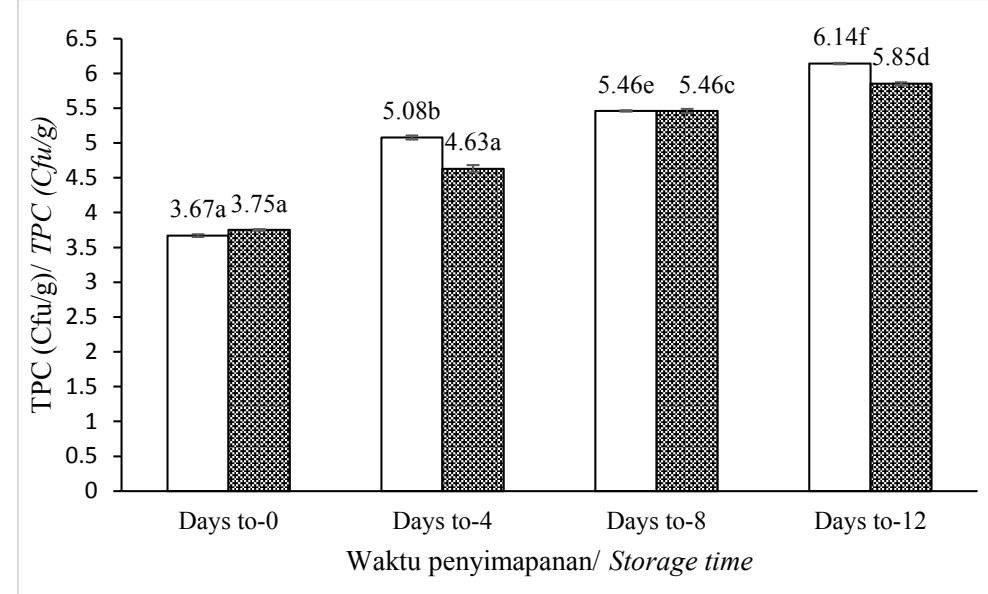

Gambar 1 Kandungan TPC udang putih selama penyimpanan dingin, kontrol $(\square)$, perendaman simplisia

Figure 1 The content of TPC shrimp white during cold storage, control ( $\square$ ), simplisia soaking ( 


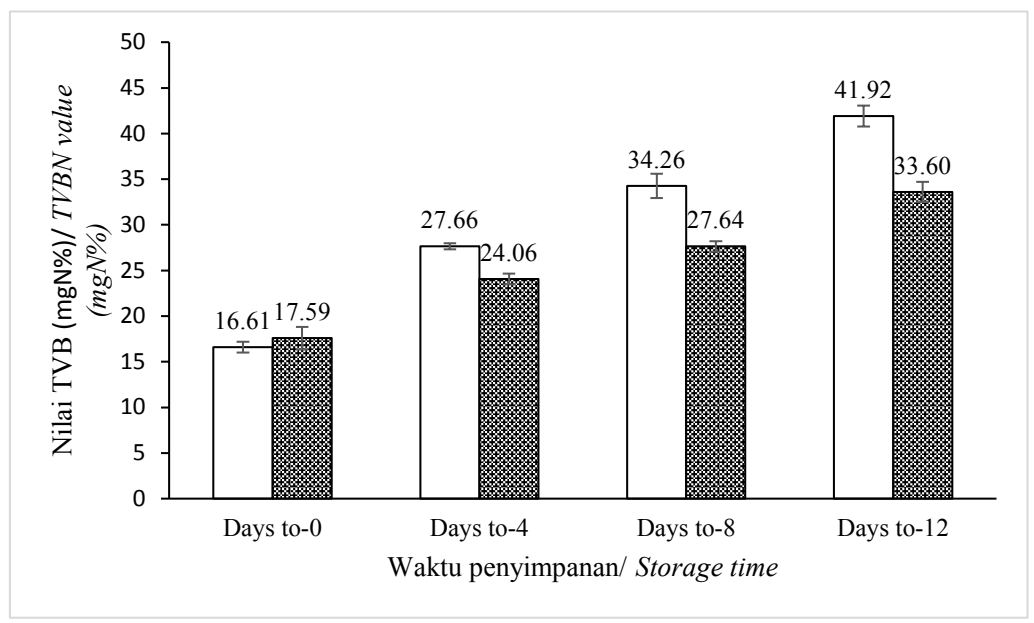

Gambar 2 Nilai TVBN udang putih selama penyimpanan dingin, kontrol ( $\square)$, perendaman simplisia

Figure 2 The content of TVBN shrimp white during cold storage, control ( $\square$ ), simplisia soaking (

Proses pembusukan oleh bakteri pembusuk akan mempercepat reaksi penguraian enzim pada udang putih tanpa perlakuan. Hasil TVBN udang putih tanpa perendaman serbuk biji pepaya memiliki nilai TVBN lebih tinggi dibandingkan dengan yang direndam dengan serbuk biji pepaya, hal ini menunjukan bahwa serbuk biji pepaya mengandung senyawa antibakteri yang cukup efektif menghambat aktivitas bakteri pembusuk sehingga dapat menghambat proses degradasi pada udang putih selama penyimpanan dingin, hal ini sejalan dengan penelitian Azizah et al. (2015), pola nilai TVBN udang terus meningkat, karena nilai TVBN menunjukan tingkat kesegaran udang yang semakin menurun, hal tersebut sejalan dengan nilai hedonik yang terus menurun dari segi tampilan bau dan tekstur selama penyimpanan.

Waryani et al. (2014) menyatakan bahwa nilai TVBN semakin meningkat seiring bertambahnya waktu penyimpanan hal ini dikarenakan TVBN merupakan senyawa hasil degradasi protein karena aktivitas enzim maupun bakteri pembusuk. Peningkatan konsentrasi TVB berhubungan dengan pertumbuhan mikroba dan dapat digunakan sebagai indikator kerusakan ikan. Banyaknya jumlah mikroba pada ikan menjadikan proses degradasi protein menjadi senyawa basa nitrogen lebih cepat sehingga konsentrasi TVBN juga meningkat.
Udang putih yang telah disimpan selama 12 hari memiliki nilai TVBN yang sejalan dengan jumlah bakteri yang terus mengalami peningkatan setiap harinya, namun berbanding terbalik dengan nilai hedonik. Nilai hedonik mempunyai hubungan yang berbanding terbalik dengan nilai log bakteri dan nilai TVBN, semakin lama penyimpanan maka nilai hedonik akan semakin menurun akan tetapi nilai dari log total bakteri meningkat demikian juga nilai TVBN (Susanto et al. 2011)

\section{pH (Derajat Keasaman)}

Pengujian $\mathrm{pH}$ bertujuan untuk menentukan tingkat keasaman atau kebasaan dari udang putih tanpa perendaman serbuk biji pepaya dan dengan perendaman serbuk biji pepaya selama penyimpanan suhu dingin. Nilai $\mathrm{pH}$ udang putih disajikan pada Gambar 3.

Perbedaan perlakuan perendaman menunjukan peningkatan $\mathrm{pH}$ dengan nilai yang berbeda. Nilai $\mathrm{pH}$ udang putih perlakuan kontrol dan dengan penambahan simplisia biji pepaya selama penyimpanan mengalami kenaikan hingga mencapai 8,4 pada hari ke-12. Kenaikan $\mathrm{pH}$ udang putih dengan perlakuan perendaman serbuk biji pepaya lebih rendah dibandingkan dengan kontrol. Perlakuan perendaman serbuk biji pepaya menunjukan perubahan $\mathrm{pH}$ yang lebih 
lambat. Kandungan alkaloid pada biji pepaya juga dapat membantu dalam memperpanjang masa simpan yaitu dengan cara menghambat pertumbuhan bakteri sehingga nilai $\mathrm{pH}$ akan bergerak naik mendekat basa dengan lambat. Menurut penelitian Torar et al. (2017), biji pepaya memiliki aktivitas antibakteri karena mengandung alkaloid (karpain) yang mampu menghambat pertumbuhan bakteri. Karpain merupakan alkaloid bercincin laktonat dengan 7 kelompok rantai metilen sehingga ampuh untuk menghambat kinerja beberapa mikroorganisme. Karpain dapat mencerna protein mikroorganisme dan mengubahnya menjadi 5 senyawa turunan bernama pepton, selain alkaloid biji pepaya juga mengandung senyawa lain yaitu flavonoid. Nilai $\mathrm{pH}$ yang terus meningkat selama penyimpanan disebabkan karena degradasi protein yang akan menghasilkan senyawasenyawa nitrogen yang lebih sederhana, diantaranya asam amino bebas dan asam basa nitrogen, meningkatnya basa-basa nitrogen akan meningkatkan pH. Suradi (2005) menyatakan bahwa aktifitas mikroba selama penyimpanan mengakibatkan terjadinya dekomposisi senyawa kimia khususnya protein yang menghasilkan senyawa yang bersifat basa dan basa kuat, sehingga proses pembusukan akan diikuti oleh peningkatan $\mathrm{pH}$.

\section{Nilai Hedonik Udang Putih}

Hedonik udang segar dilakukan untuk mengetahui apakah udang putih tersebut masih dalam standar dan layak untuk dikonsumsi atau tidak. Pengujian hedonik dilakukan dengan menggunakan scoresheet udang segar menurut standar BSN (2006) dan dilakukan penilaian oleh 30 panelis, dengan melihat parameter tampilan, bau dan tekstur. Hasil pengujian hedonik udang putih dengan perendaman serbuk biji pepaya dan tanpa perendaman disajikan pada Gambar 4.

Berdasarkan pengujian hedonik diperoleh nilai hedonik yang mengalami penurunan dengan semakin lama masa simpan. Nilai hedonik dari kedua perlakuan tidak berbeda nyata sampai penyimpanan hari ke-4. Perlakuan tanpa perendaman pada hari ke-8 sudah tidak layak konsumsi dengan nilai 6,6 sedangkan perlakuan dengan perendaman serbuk biji pepaya pada hari ke-12 dengan nilai 6,7. Udang putih yang tidak layak konsumsi memiliki karakteristik tampilan utuh, kusam, mulai timbul bau amoniak dan tekstur tidak elastis dengan nilai dibawah 7,00 . Nilai hedonik yang menurun dengan cepat dikarenakan perbedaan jumlah dan aktivitas senyawa antibakteri pada masingmasing bahan alami sehingga menimbulkan efek yang berbeda pada tingkat penurunan nilai hedonik (Susanto et al. 2011).

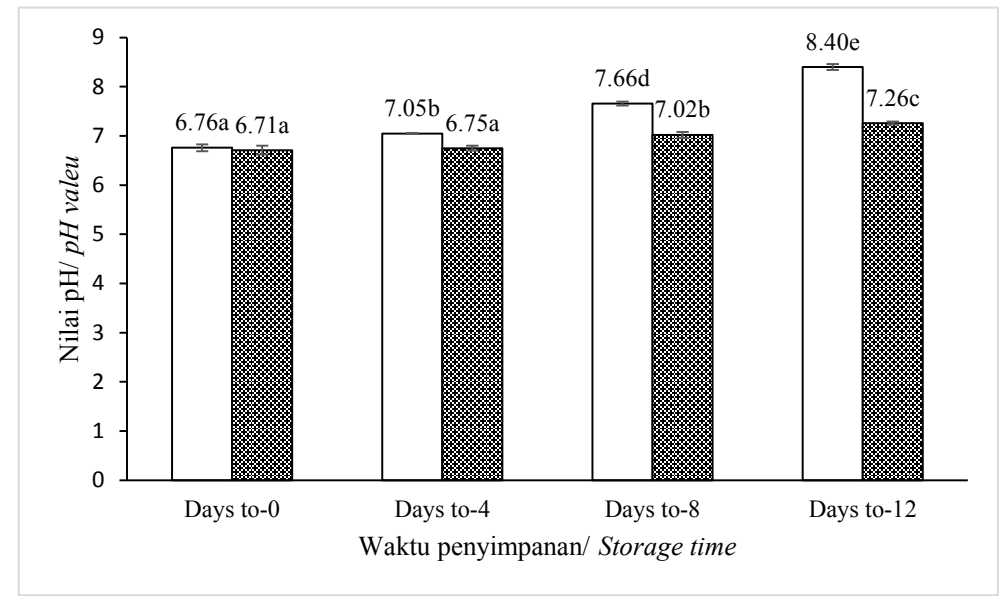

Gambar 3 Kandungan $\mathrm{pH}$ udang putih selama penyimpanan dingin, kontrol ( $\square$ ), perendaman simplisia

Figure 3 The content of $\mathrm{pH}$ of shrimp white during cold storage, control ( $\square$ ), simplisia soaking ( 


\section{Tampilan}

Nilai tampilan perlakuan tanpa perendaman memberikan pengaruh yang nyata selama penyimpanan. Hal ini dikarenakan nilai tampilan terus menurun secara signifikan untuk sampel tanpa perlakuan selama penyimpanan. Berbeda dengan perlakuan perendaman serbuk biji pepaya yang memiliki nilai penurunan yang stabil selama penyimpanan. Pengamatan hari ke-0 hingga hari ke-4 untuk sampel tanpa perlakuan kondisi udang masih dikatakan layak konsumsi, sedangkan pada perlakuan perendaman serbuk biji pepaya pada hari ke-8 masih dikatakan layak konsumsi. Hari ke-8 udang putih kontrol memiliki nilai 6,4 dan perendaman serbuk biji pepaya hari ke12 memiliki nilai 6,6 dimana sudah tidak layak dikonsumsi. Menurut standar BSN (2006), nilai hedonik minimal 7. Penurunan nilai hedonik tampilan menunjukan bahwa terjadi pembusukan selama penyimpanan. Berdasarkan penelitian Karnila et al. (2006), tahap pre-rigor udang galah $(M$. rosenbergii) berlangsung selama 2,5 jam setelah udang tersebut mati yang ditandai dengan daging yang bertekstur lembut dan lentur serta bau yang sangat segar. Nilai hedonik udang pada tahap ini yaitu 8,9 untuk tahap rigor mortis udang galah ( $M$. rosenbergii) terjadi selama 6,5 jam yang dimulai dengan mengejangnya otot dan tubuh mulai melengkung serta bau yang masih spesifik segar. Nilai hedonik udang pada tahap ini yaitu 7,1-8,6 sedangkan pada tahap post-rigor udang galah (M. rosenbergii) terjadi pada jam ke-12 setelah udang mati yang ditandai dengan melunaknya daging, keluarnya cairan hitam dari tubuh udang serta timbulnya bercak kemerahan pada bagian kepala, kaki dan antenna, pada tahap ini nilai hedonik kesegaran udang yaitu 5 .

\section{Bau}

Nilai hedonik pada parameter bau udang putih tanpa perendaman dan dengan perendaman serbuk biji pepaya mengalami penurunan selama penyimpanan. Awal penyimpanan, bau udang putih tanpa perendaman serbuk biji pepaya mempunyai bau spesifik jenis sesuai dengan SNI No 01-2728-2006, bau udang segar yaitu segar spesifik jenis. Hari ke-8 penyimpanan, udang putih tanpa perendaman memiliki nilai hedonik bau berkisar 6,7 dengan bau amoniak udang putih tersebut sudah tidak layak konsumsi sedangkan pada perlakuan perendaman serbuk biji pepaya udang putih sudah tidak layak dikonsumsi pada hari ke12 dengan nilai 6,6. Udang putih dengan tanpa perendaman memiliki nilai hedonik bau yang sudah mulai ditolak pada hari ke-8, sedangkan nilai hedonik bau pada udang putih dengan perendaman serbuk biji pepaya masih dapat diterima sampai hari

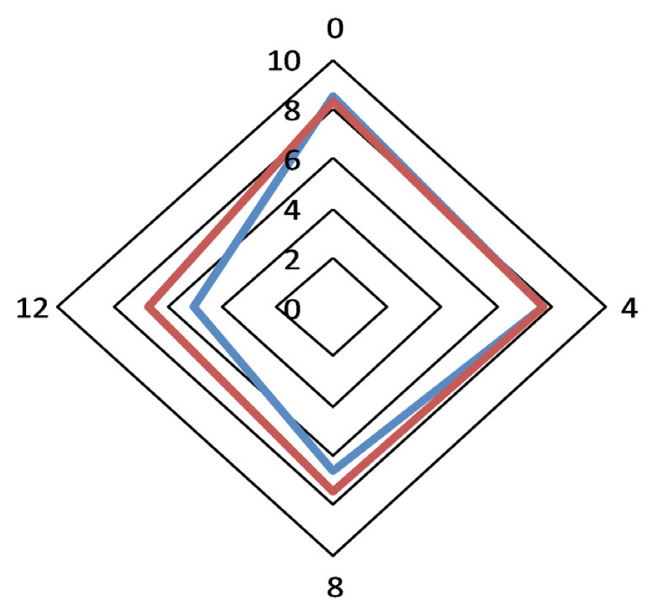

Gambar 4 Nilai organoleptik udang putih selama penyimpanan dingin. \% ( $\square$ ), $4 \%$ (

(Figure 4 Organoleptic value of white shrimp during cold storage 0\% ( $\square$ ), $4 \%$ ( 
ke-8. Bau busuk yang ditimbulkan udang putih pada akhir penyimpanan disebabkan karena menguapnya basa-basa volatile yang disebabkan oleh degradasi protein sehingga terbentuknya senyawa amoniak yang akan memberikan bau busuk, hal ini diperkuat oleh Farahita et al. (2012), bakteri yang merombak protein akan menghasilkan enzim proteolitik yang mengakibatkan protein menjadi ikatan peptida yang pendek dan asam amino yang terbentuk menjadi senyawa amin dan amoniak yang akan memberikan bau tajam dan cita rasa yang khas.

\section{Tekstur}

Perlakuan dengan perendaman serbuk biji pepaya cenderung turun dengan stabil, tidak seperti udang putih tanpa perlakuan perendaman yang turun signifikan, terjadi perbedaan nyata antara perlakuan dan lama penyimpanan. Tekstur udang putih dengan perendaman serbuk biji pepaya konsentrasi $4 \%$ terlihat lebih padat, kompak dan elastis pada hari ke- 4 sampai hari ke-12 dibandingkan dengan udang putih tanpa perendaman serbuk biji pepaya. Tekstur udang putih pada hari ke-8 untuk perlakuan tanpa perendaman sudah lunak dan kurang elastis dengan rata-rata nilai hedonik tekstur sebesar 6,6 sedangkan untuk udang putih dengan perendaman serbuk biji pepaya pada hari ke-8 masih cukup baik dengan rata-rata nilai hedonik tekstur sebesar 7,1. Menurut penelitian Jannah et al. (2014), hasil uji hedonik tekstur udang putih selama penyimpanan dingin terdapat perbedaan yang nyata untuk kedua jenis perlakuan (kontrol dan lengkuas), pada hari ke-0 sampai ke-3, tekstur kompak dan padat namun pada hari ke-6 sampai ke-9, kekompakan daging udang berkurang, hal ini dikarenakan kadar formalin berkurang seiring dengan berjalannya masa simpan pada suhu dingin. Walaupun tingkat keelastisan berkurang, namun udang yang diberi formalin teksturnya masih lebih baik karena formalin menyebabkan jaringan daging udang menjadi lebih kompak.

\section{KESIMPULAN}

Udang putih segar yang disimpan dengan menggunakan konsentrasi serbuk simplisia biji pepaya $4 \%$ mampu bertahan hingga hari ke-12 dibandingkan dengan udang putih segar tanpa perlakuan (kontrol) yang hanya bertahan hingga hari ke-8, penambahan konsentrasi serbuk simplisia biji pepaya yang bedaan dan lama penyimpanan memberikan pengaruh nyata terhadap nilai TPC, TVBN, nilai $\mathrm{pH}$ serta nilai hedonik $(\mathrm{p}<5 \%)$.

\section{UCAPAN TERIMA KASIH}

Ucapan terima kasih disampaikan kepada Universitas Diponegoro atas Dana Hibah Penelitian Mahasiswa tahun 2016.

\section{DAFTAR PUSTAKA}

Ahmad AR, Sakinah, Wisdawati, Asrifa WA. 2014. Study of antioxidant activity and determination of phenol and flavonoid content of peptino's leaf extract (Salmon muricatum Aiton). International Journal of Pharm Teach Research. 6(2): 600-606.

Alfiyaturohmah N, Rachmawati, Tjahjaningsih W. 2011. Pengaruh ekstrak alga cokelat (Sargassum sp.) terhadap pertumbuhan bakteri Eschericia coli secara in vitro. Jurnal Ilmiah Perikanan dan Kelautan. 3(1): 79-83.

Azizah LH. 2015. Analisis kemunduran mutu udang vaname (Litopenaeus vannamaei) secara kimiawi dan mikrobiologis. Jurnal Ilmiah Perikanan dan Kelauatan. 4(1): 69-72.

[BSN] Badan Standarisasi Nasional. 2004. Cara Uji Derajat Keasaman (pH) dengan Menggunakan Alat $\mathrm{pH}$ Meter SNI 06-6989.11-004. Jakarta (ID): Badan Standarisasi Nasional.

[BSN] Badan Standarisasi Nasional. 2006. Cara Uji Mikrobiologi Bagian 3: Penentuan Angka Lempeng Total (ALT) pada Produk Perikanan No. SNI 01-2332.32006. Jakarta (ID): Badan Standarisasi Nasional.

[BSN] Badan Standarisasi Nasional. 2006. Udang Segar No. SNI 01-2728.1-2006. Jakarta (ID): Badan Standarisasi Nasional.

[BSN] Badan Standarisasi Nasional. 2006. Petunjuk Pengujian Hedonik dan Sensori No. SNI 01-2346.3-2006. Jakarta (ID): Badan Standarisasi Nasional.

[BSN] Badan Standarisasi Nasional. 2009. Penentuan Kadar Total Volatil Base 
Nitrogen (TVBN-N) dan Trimetil Amin Nitrogen (TMA-N) pada produk Perikanan No. SNI 2354.8.2009. Jakarta (ID): Badan Standarisasi Nasional.

Husni A, Brata AK, Budhiyanti S. 2015. Peningkatan daya simpan ikan kembung dengan ekstrak etanolik Padina sp. selama penyimpanan suhu kamar. Jurnal Pengolahan Hasil Perikanan. 18(1): 1-10.

FarahitaY, Julianto N. Kurniawati. 2012. Karakteristik kimia Caviar Nilem dalam perendaman campuran larutan asam asetat dengan larutan garam selama penyimpanan suhu dingin $\left(5-10^{\circ} \mathrm{C}\right)$. Jurnal Perikanan dan Kelautan. 3(4): 165170.

Jannah M, Farid WM, Surti T. 2014. Efektifitas lengkuas (Alpina galarga) sebagai pereduksi kadar formalin pada udang putih (Penaeus merguensis) selama penyimpanan dingin. Jurnal Pengolahan dan Bioteknologi Hasil Perikanan. 3(1): 70-79.

Karnila R, Suparmi, Romaida M. 2006. Kajian sifat mutu udang galah (Macrobrachim rosenbregii) segar pada penyimpanan suhu kamar. Jurnal Berkala Perikanan Terubuk. 33(2): 121-125.

Liviawaty E, Afrianto E. 2010. Penanganan Ikan Segar. Bandung (ID): Widya Padjadjaran.

MarlinR, Marwoto J, Salni. 2015. Uji aktivitas fraksi buah blimbinng wuluh (Averrhoa blimbi L) terhadap Jamur Candida albicons secara in vitro. 2(1): 62-72.

Martiasih M, Sidharta BBR, Atmojo PK. 2014. Aktivitas antibakteri ekstrak biji pepaya (Carica papaya L.) terhadap Escherichia coli dan Streptococus pyogenes. Jurnal Teknologi. 4(1): 59-62.

Masduqi A, Munifatul FI, Erma P. 2014. Efek metode pengeringan terhadap kandungan bahan kimia dalam rumput laut Sargassum polycystrum. Jurnal Anatomi dan Fisiolgi. 112(1): 1-9.

Mien DJ, Carolin WA, Firhani PA. 2015. Penetapan kadar saponin pada ekstrak daun lidah mertua (Sansevieria Trifasciata Prain Varietas S. Laurentii) secara gravimetri. Jurnal Ilmu dan Teknologi Kesehatan. 2(2): 65-69.
Mulyono LM. 2013. Aktivitas Antibakteri ekstrak etanol biji pepaya (Carica papaya L.) terhadap Escherichia coli dan Staphylococcus aureus. Jurnal Ilmiah Mahasiswa Surabaya. 2(2): 23-34.

Novrihansa S, Kamila R, Nurbaya. 2013. Riset Kesehatan Ikan dan Lingkungan Budidaya Air Payau. BPPKP. Balai Penelitian dan Pengembangan Budidaya Air Payau. Maros.

NuriaM, Faizatun CA, Suantri. 2009. Uji aktifitas antibakteri ekstrak etanol daun jarak pagar (Jatropha curcas L.) terhadap bakteri Staphylococcus aureus Atcc 25923, Escherichia coli Atcc 25922, dan Salmonella thyphi Atcc 1408. Jurnal Ilmu Ilmu Pertanian. 5(2): 26-27.

Peter K, Kumar JY, Pandey P, Masih H. 2014. antibacterial activity of see and leaf extract of Carica papaya Var. Pusa dwarf Linn. Journal of Pharmacy and Biological Sciences. 9(2): 29-37.

Rizqiyana N, Komala O, Yulia I. 2017. Formulasi deodoran roll on ekstrak daun beluntas (Pluchea indica L.) sebagai antibakteri terhadap Staphylococcus epidermis. Jurnal Farmasi. 3(6): 45-54.

Ryanata E, Palupi S, Azminah. 2015. Penentuan jenis tanin dan penetapan kadar tanin dari kulit buah pisang masak (Musa paradisica L.) secara spektrofotometri dan permanganometri. Jurnal Ilmiah Mahasiswa Universitas Surabaya. 4(1): 1-16.

Samin AA, Bialangi NY, Salimi K. 2014. Penentuan kandungan fenolik total dan aktivitas antioksidan dari rambut jagung (Zea mays L.) yang tumbuh di daerah gorontalo. Jurnal Teknologi Pangan. 5(1): $312-323$.

Sembiring BBR. 2010. Status teknologi pasca panen sambiloto (Andrographis paniculata Needs). Jurnal Farmasi. 134144.

Suparno NS. (2012). Pengolahan Udang Beku. Kumpulan Hasil-hasil Penelitian Pascapanen Perikanan. Jakarta(ID): Puslitbang Perikana

Suradi K. 2005. Aplikasi model arrhenius untuk pendugaan penurunan masa simpan daging sapi pada penyimpanan 
suhu ruang dan refrigerasi berdasarkan nilai TVB dan $\mathrm{pH}$. Jurnal Penelitian SPeSia. 2(4): 305-308.

Susanto ET, Agustini W, Swastawati F, Surti T, Fahmi AS, Muhamud FA, Muhammad KN. 2011. Pemanfaatan bahan alami untuk memperpanjang umur simpan ikan kembung (Restrellinger negletus). Jurnal Perikanan. 13(2): 60-69.

Taufiq S, Yuniarti U, Siti H. 2015. Uji aktivitas antibakteri ekstrak etanol biji buah pepaya (Carica papaya L.) terhadap Escherichia coli dan Salmonella typhi. Jurnal Penelitian SPeSIA. 5(2): 655-659.
Torar GMJ, Lolo WA, Citranigtyas G. 2017. Uji aktivitas antibakteri ekstrak etanol biji (Carica papaya L.) terhadap bakteri Pseudomonas aerusginosa dan Staphylococcus aureus. Jurnal Ilmiah Farmasi. 6(2): 232-243.

Triwibowo R, Rachmawati N, Hermana I. 2013. Penggunaan Cetyperdinium Chloride sebagai antibakteri pada udang. Jurnal Penelitian SPeSIA. 6(2): 55-59.

Waryani SW, Silvia R, Hanum F. 2014. Pemanfaatan kitosan dari cangkang (Achatina fulica). Jurnal Veteriner. 5(1): 36-40. 